\title{
Learning pain neuroscience education from the WHOQOL-Bref instrument in the classroom. Case reports
}

\author{
Aprendendo a educação em neurociência da dor por meio do instrumento WHOQOL-Bref em \\ sala de aula. Relato de casos
}

Kênia Fonseca Pires ${ }^{1}$, Tatiana Andrade Cacho', Luiza Nolêto dos Santos ${ }^{1}$

DOI 10.5935/2595-0118.20190017

\section{ABSTRACT}

BACKGROUND AND OBJECTIVES: During the undergraduate course students have the opportunity to learn and understand health promotion and prevention, quality of life and other concepts, but they rarely learn about health education, let alone pain. Knowing that there are gaps in the training of health professionals regarding pain, and in the use of pedagogical methodologies that encourage the active construction of knowledge, the objective of this study was to provide an experience about the process of understanding pain neuroscience education from an instrument and the role-playing technique in the academic environment of Physiotherapy students.

CASE REPORTS: During a Basic Complexity class, Physiotherapy students from the Ceilândia campus of the University of Brasília were invited to provide care to a fictitious population and develop explanations and lessons about pain and its processes in the human body using the WHOQOL-Bref questionnaire to evaluate the quality of life of the individual and target the care accordingly.

CONCLUSION: The experience provided by the simulation of clinical cases was important for the analysis and discussion of challenging issues such as psychological, social and behavioral factors in the health education process in multi and interdisciplinary interventions.

Keywords: Pain neuroscience education, Quality of life, Simulation of clinical cases, WHOQOL-Bref.

\footnotetext{
Luiza Nolêto dos Santos - Dhttps://orcid.org/0000-0001-5360-9088;

Tatiana Andrade Cacho - (Dhttps://orcid.org/0000-0001-8523-5527;

Kênia Fonseca Pires - Dhttps://orcid.org/0000-0001-5176-4025.

Submitted in August 16, 2018

Accepted for publication in January 07, 2019

Conflict of interests: none - Sponsoring sources: none

Correspondence to:

Campus Universitário - Centro Metropolitano, Ceilândia Sul

72220-275 Brasília, DF, Brasil.

E-mail: keniafonsecapires@gmail.com

(C) Sociedade Brasileira para o Estudo da Dor
}

1. Universidade de Brasília, Faculdade de Ceilândia, Curso de Fisioterapia, Brasília, DF, Brasil.

\section{RESUMO}

JUSTIFICATIVA E OBJETIVOS: Durante a graduação, os acadêmicos têm a oportunidade de aprender e compreender sobre promoção e prevenção de saúde, qualidade de vida, entre outros conceitos, mas raramente a educação em saúde é colocada nas salas de aula, em especial o entendimento da dor. Sabendo que há lacunas na formaçáo de profissionais de saúde relacionadas ao conhecimento da dor e à utilizaçấo de metodologias pedagógicas que incentivem a construçáo ativa do conhecimento, o objetivo deste estudo promoveu um relato de experiência sobre o processo de entendimento e educação em neurociência da dor, por meio de um instrumento e da técnica de dramatizaçấo na vivência acadêmica de estudantes de Fisioterapia.

RELATO DOS CASOS: Durante a realizaçáo de uma aula de Básica Complexidade, alunos do curso de Fisioterapia da Universidade de Brasília - Campus Ceilândia, foram convidados a vivenciarem um atendimento à uma população fictícia e desenvolverem explicaçóes e ensinamentos sobre a dor e seus processos no corpo humano, utilizando o instrumento WHOQOL-Bref para avaliar a qualidade de vida do indivíduo e direcionar o seu atendimento.

CONCLUSẲ: A experiência vivenciada por meio de simulaçôes de casos clínicos na disciplina foi importante para a análise e discussão de questôes desafiadoras como fatores psicológicos, sociais, e comportamentais no processo de educação em saúde em intervençôes multi e interdisciplinar.

Descritores: Educação em neurociência da dor, Qualidade de vida, Simulaçôes de casos clínicos, WHOQOL-Bref.

\section{INTRODUCTION}

Educational interventions around the theme of pain refer to the usability of knowledge of anatomy, physiology, and pharmacology of pain, and also to understanding how the correct approach and the treatment of the syndrome can reduce the physical and emotional consequences resulting from the pain process ${ }^{1,2}$.

Studies with a systematic review on education in pain neuroscience $(\mathrm{EPN})$ for musculoskeletal pain supply evidence that EPN improves the appropriate classification of pain, incapacity, mobility, the use of health services, and also attitudes and patterns of behavior related to pain, including catastrophization, fear, and avoidance ${ }^{3}$.

On the other hand, one issue that has called the attention of investigators is the fact that nociception is not sufficient to evoke pain, but also psychological and social factors are important for the de- 
velopment of chronic illnesses ${ }^{4}$. In this regard, the teaching of pain issues has become necessary as part of the qualification of health professionals, and for the careful handling of the symptom ${ }^{5}$.

In this context, one of the courses in the health area that goes through this process of change, to qualify the professionals who work with the Brazilian Unified Health System (SUS), is the Physiotherapy course.

Starting from this premise and considering that the SUS is a major employer of workers in the health sector, the education of students should be encouraged to aim at a humanist style of action, which is critical, reflexive and generalist. This means that, with the constant union of theory and practice within the University environment, one can produce conscientious professionals, who are engaged in seeking to modify the environment in which they live, also having an attitude that may change the ills in the health sector ${ }^{6}$.

The multidimensional construct of quality of life (QoL) known as the World Health Organization Quality of Life (WHOQOL-Bref) was proposed as an indicator of the general health of the population. The application of this instrument is used to encourage actions for the promotion of health. It is speculated that the use of the questionnaire, together with the EPN tool, could add knowledge when interpreting the different dimensions of human health, such as psychological health, the degree of independence, the social relationships, the environment, and spiritual standards. They can also be used in academic circles after the elaboration of problem situations, and also to promote changes in the teaching and learning process, with regards to pain ${ }^{7,8}$.

From this perspective, the study promoted a report on experiences regarding the process of understanding and education within the study of pain, through an instrument and the role-playing technique within the academic experience of Physiotherapy students.

\section{CASE REPORTS}

An academic study based on real-life experiences was carried out at the Ceilândia Campus of the University of Brasilia to achieve the proposed goal.

For this purpose, the academic students of the $6^{\text {th }}$ semester of the Physiotherapy course were initially separated into two groups, namely physiotherapist student $(\mathrm{PhS})$ and patient-student $(\mathrm{PtS})$. Later on, after this division, they were asked to simulate the care to three clinical cases, so that they could provide grounds for teachings and explanations about pain and neurophysiological processes in the human body.

Case 1. Patient aged 70 years old, had pain when moving the joints of the shoulders and knees, making it much more difficult to carry out daily activities such as cleaning the house, taking care of the dog, and putting clothes out to dry on the clothesline. This patient said that he could not understand why the pain was present, and why his health did not improve with the drugs taken daily. This patient also heard about a physical activity group that had sessions twice a week, and showed significant interest, believing that physical activities could help to improve the loss of strength of the lower limbs.

Case 2. This patient is a 45-year-old homemaker and reported that she had spinal pain for 15 years. Two years ago, after having an X-ray of the spine, the doctor said that the patient had spinal problems and she would need to do physical exercises. She believed and reported that she could have a disc herniation. The patient did not show the X-ray, as she didn't know where it was. She also reported that she does not like to do physical exercises and does not understand why things improve with exercises. She also said that she is unable to pay to work out at a fitness center and that her dream was to be a ballerina. She showed great difficulty when getting down and when carrying her supermarket shopping. She is $155 \mathrm{~cm}$ tall and weighs $105 \mathrm{~kg}$.

Case 3. This patient is 65 years old, retired, and cares for her 95 -yearold mother. Together with her mother, she carries out all household chores and especially special care: bathing her mother, cooking and the routine walks. She complains of muscular fatigue in general and joint pain. She does not sleep well, and only gets some 4 hours of sleep a night. She does not have any time to herself, to enjoy the company of her friends. However, she heard of the group and went over to understand more about pain, and also to know what can be done at home to make her more energetic.

The WHOQOL-Bref questionnaire was used to evaluate the quality of life (QoL) of the clinical cases, through a battery of 26 questions. Questions 1 and 2, about general QoL and perception of health respectively, with a score from 1 to 5 . The other 24 questions referred to the four domains: Physical, Psychological, Social Relations, and the Environment, also with a score from 1 to 5 points, it being necessary to reencode the point values of questions 3, 4 and 26 . The mean of the values obtained shall be calculated from the total point score, divided by the number of questions present in the same domain $^{7}$ (Annex 1).

For the lived-experience report, the participants produced a video, approximately 10 minutes long, and then simulated a physiotherapeutic appointment for a fictitious patient, with the following objectives:

- Instruct the patient to understand his or her pain (possible causes, and which neural and brain mechanisms were activated);

- Improve the QoL through understanding pain.

Thus, the $\mathrm{PtS}$ group was given the clinical case of the teacher of the subject, and the guidance was to take the clinical case, presenting the current and past history of the disease, symptoms, facial expressions, deficits of movement, falls from own height, feelings, emotions, beliefs, and catastrophization.

Similarly, the $\mathrm{PhS}$ group was advised, by the teacher, to evaluate and apply the questionnaire and then proceed with the calculations and discuss interventions for each case. At the same time, the $\mathrm{PhS}$ group was asked to plan and execute EPN, with a neurophysiological explanation of the clinical case and guidance on the ongoing education process for activities at home.

During the academic experience, the $\mathrm{PhS}$ group should then make use of the data obtained through the WHOQOL-Bref questionnaire, and interpret the values for each domain as described above: WHOQOL-Bref - case 1: the physical domain had the smallest mean (1.83) when compared with the psychological, social relations and environment domains. 
WHOQOL-Bref - case 2: the physical domain had the lowest mean (1.71) when compared with cases 1 and 3 , and in the environmental domain the mean obtained was 2.0 .

WHOQOL-Bref - case 3: the domain of the social relation showed a much lower mean (1.0) when compared to the physical, psychological, and environment domains.

After the interpretation of the domains, guidance was aimed at better catering to the needs of the $\mathrm{PtS}$ group. Also, this being an experience within an environment of Basic Complexity, the $\mathrm{PhS}$ group should encourage the individual's participation and also present the funds offered and which best fit the individual needs as presented by the $\mathrm{PtS}$ group.

\section{DISCUSSION}

Simulations with clinical cases were based on the handling of EPN, in a move to check the altered perceptions of knowledge of the neurophysiology of pain, and how beliefs could trigger the increase in chronic pain ${ }^{3,9,10}$.

The QoL is a multidimensional construct proposed as an indicator of the general health of the population, and the interpretation thereof is used to encourage actions in the promotion of health ${ }^{11}$ as presented by the $\mathrm{Pt} S$ group.

From this standpoint, the WHOQOL-Bref instrument guided the educational approach, giving priority to the physical and personal relations domains, and their issues, to be worked upon by the $\mathrm{PhS}$ group. The instrument also values individual perception and can assess QoL in different groups and situations, regardless of the educational level'. On considering the means within the physical domain, for the cases involved (1,2 and 3), we obtained a variation from 1.71 to 2.85 , with Case 2 presenting the lowest of the results, with 1.71. This domain includes issues such as pain and discomfort, energy and fatigue, mobility, activities of daily life, dependence on drugs or treatment, ability to work.

The evaluation of the physical domain showed a need to monitor the indices of quality of life (QoL) in patients with chronic diseases, and plan strategies for intervention, as these provide important information about the user, allowing the identification of priorities and also offering grounds for health programmes to implement effective action and thus provide a better quality of life to users, within primary health care.

This applies to the interpretation of the issues raised in Case 1, which showed a lower level of QoL in the physical domain when compared with the other domains: psychological, personal relations, and the environment. In the opinion of many specialists, this aspect is key when considering the quality of life of the elderly, which is influenced as age increases ${ }^{11,12}$.

We found no cut-off points in the literature that would establish scores above or below. In this study, we analyzed copies of the individual scores obtained by each respondent within each domain, in the 3 cases studied, and then an association was established with a Likert scale with 5 items ( $1=$ very poor, $2=$ poor, $3=$ average; $4=\operatorname{good}$ and $5=$ very good) for the 24 questions that make up the instrument ${ }^{13}$.

With regards to the evaluation of case 2 , we saw that it has the lowest mean within the physical domain and lower levels of means for the psychological and environmental domains; the general assessment of the perception of quality of life was neither good nor bad. This data is linked to the study of three Basic Health Units (UBSs), in the Brazilian state of Rio Grande do Sul, that analyzed the means of the physical domain and concluded that they were lower in female patients who did not live with a partner and had some chronic disease ${ }^{14,15}$.

As observed in Case 2, there was a low score for the environmental domain for the questions related to financial resources and the physical environment. This analysis corroborates studies where patients of lower social classes showed a worse quality of life, highlighting the fact that, in Brazil, the unequal distribution of wealth, together with illiteracy, low educational level, poor housing conditions, and precarious environment, all had a negative impact on the quality of life and the health of the subjects ${ }^{11,16}$.

The lowest score observed for the domain of the personal relations, in case 3, confirmed other results that described the perception that there was a lower quality of life among women, people of more advanced age, people of lower social strata, who did not live with a partner, and having some chronic disease. From there, one can conclude that the absence of a partner can trigger feelings of solitude and isolation, in turn causing a lower level of well-being ${ }^{13,14}$.

In this way, through experience stimulated by clinical cases, this instrument allows one to discuss the possible subjective perception of his or her physical and psychological health, as well as social relations and the environment in which the person lives ${ }^{7,11}$.

Educational strategies based on simulations have been commonly used for teaching Communication and Relationship Skills, especially in the health area ${ }^{17}$. These strategies seek to get the students included in the teaching process through assisted and guided practice. Simulation allows the students to experience the representation of a real event, to practice, learn, appraise, test, or understand human systems or actions ${ }^{10,17}$.

It is within this understanding that it was possible to analyze and discuss skills among the students, in issues involving the interpretations of the physical and psychological health dimensions, level of independence, social relationships, the environment, and spiritual level ${ }^{11,18}$. The videos that reproduce the EPN were analyzed through oral presentations, followed by a debriefing which is considered the most important part of the simulation, and which allows the critical analysis of the planning process and the relationship established between the $\mathrm{PhS}$ and $\mathrm{Pt} \mathrm{S}^{18}$.

The requests for debriefing consisted of acting out the scene, highlighting how they were feeling during the physiotherapeutic evaluation and as Physiotherapy professionals, and also listing the strengths of their actions and points that could be improved. The purpose of the academic experiences described was to meet what is set forth in the National Curriculum Guidelines for the Physiotherapy course, using methodologies and criteria to monitor and evaluate the teaching-learning process ${ }^{19}$.

\section{CONCLUSION}

The results of the reports on the experiences in the classroom suggest that possibly the simulation of clinical cases allowed the students to experience the representation of a real event and that the WHOQOL-Bref instrument gave value to the individual perception, making it possible to evaluate QoL in different groups and situations. 
Annex 1. The WHOQOL-Bref Test

\begin{tabular}{|c|c|c|c|c|c|c|}
\hline Questions 1 and 2 & Case 1 & Case 2 & Case 3 & & & \\
\hline 1. Perception of quality of life & 3 & 3 & 2 & & & \\
\hline 2. Satisfaction with state of health & 3 & 3 & 3 & & & \\
\hline Domain I - Physical & Case 1 & Mean & Case 2 & Mean & Case 3 & Mean \\
\hline 3.Pain and discomfort & 2 & \multirow{7}{*}{1.83} & 2 & & 3 & \multirow{7}{*}{2.85} \\
\hline 4. Energy and fatigue & 2 & & 2 & & 4 & \\
\hline 5.Sleep and rest & 2 & & 2 & & 4 & \\
\hline 6.Mobility & 1 & & 1 & 1.71 & 3 & \\
\hline 7.Activities of daily life routine & 2 & & 2 & & 1 & \\
\hline 8.Dependence on drugs or treatments & 1 & & 2 & & 3 & \\
\hline 9.Ability to work & 1 & & 1 & & 2 & \\
\hline Domain II - Psychological & Case 1 & Mean & Case 2 & Mean & Case 3 & Mean \\
\hline 10. Positive feelings & 2 & \multirow{6}{*}{2.66} & 3 & \multirow{6}{*}{2.33} & 1 & \multirow{6}{*}{2.83} \\
\hline 11. Thinking, learning, memory, and concentration & 3 & & 3 & & 3 & \\
\hline 12. Self-esteem & 3 & & 2 & & 4 & \\
\hline 13. Body image and appearance & 3 & & 1 & & 4 & \\
\hline 14. Negative feelings & 1 & & 2 & & 2 & \\
\hline 15. Spirituality, religion and personal beliefs & 4 & & 3 & & 3 & \\
\hline Domain III - Social relationships & Case 1 & Mean & Case 2 & Mean & Case 3 & Mean \\
\hline 16. Personal Relationships & 2 & \multirow{3}{*}{3.0} & 3 & & 1 & \multirow{3}{*}{1.0} \\
\hline 17. Social Support & 2 & & 1 & $2 . .33$ & 1 & \\
\hline 18. Sexual Activity & 2 & & 3 & & 1 & \\
\hline Domain IV - Environment & Case 1 & Mean & Case 2 & Mean & Case 3 & Mean \\
\hline 19. Physical security and protection & 2 & \multirow{8}{*}{2.5} & 2 & \multirow{8}{*}{2.0} & 3 & \multirow{8}{*}{2.75} \\
\hline 20. Home environment & 2 & & 2 & & 4 & \\
\hline 21. Financial resources & 2 & & 1 & & 2 & \\
\hline 22. Health care and social care: availability and quality & 3 & & 2 & & 2 & \\
\hline 23. Opportunities to acquire new information and skills & 2 & & 2 & & 3 & \\
\hline 24. Participation and opportunities for, recreation and leisure & 3 & & 3 & & 4 & \\
\hline 25. Physical environment: pollution/noise/traffic/weather & 4 & & 1 & & 2 & \\
\hline 26. Transportation & 2 & & 3 & & 2 & \\
\hline
\end{tabular}

\section{REFERENCES}

1. Moseley GL, Butler DS. Fifteen years of explaining pain: the past, present, and future. J Pain. 2015;16(9):807-13.

2. Moseley L. Combined physiotherapy and education is efficacious for chronic low back pain. Aust J Physiother. 2002;48(4):297-302.

3. Louw A, Zimmey K, Puentedura EJ, Diener I. The efficacy of pain neuroscience education on musculoskeletal pain: a systematic review of the literature. Physiother Theory Pract. 2016;32(5):332-55.

4. Moseley L. Unravelling the barriers to reconceptualization of the problem in chronic pain: the actual and perceived ability of patients and health professionals to understand the neurophysiology. J Pain. 2003;4(4):184-9.

5. Louw A, Zimney K, O'Hotto C, Hilton S. The clinical application of teaching people about pain. Physiother Theory Pract. 2016;32(5):385-5.

6. Figueiredo TC, Rhoden EC. "Fisioterapia e a promoção da saúde": o saber em saúde a partir do ensino acadêmico. Rev Epidemiol Control Infect. 2014;4(1):32-3.

7. Fleck MP, Louzada S, Xavier M, Chachamovich E, Vieira G, Santos L, et al. [Application of the Portuguese version of the abbreviated instrument of quality life WHOQOL-bref]. Rev Saude Publica. 2000;34(2):178-83. Portuguese.

8. DeSantana JM, Souza JB, Reis FJ, Gosling AP, Paranhos E, Barboza HF, et al. Currículo em dor para graduação em Fisioterapia no Brasil. Rev Dor. 2017;18(1):72-8.

9. Nijs J, Paul van Wilgen C, Van Oosterwijek J, van Ittersum M, Meeus M. How to explain central sensitization to patients with 'unexplained' chronic musculoskeletal pain: practice guidelines. Man Ther. 2011;16(5):413-8.

10. Louw A, Puentedura EL, Zimney K. Teaching patients about pain: it works, but what should we call it? Physiother Theory Pract. 2016;32(5):328-31.

11. Almeida-Brasil CC, Silveira MR, Silva KR, Lima MG, Faria CD, Cardoso CL, et al. [Quality of life and associated characteristics: aplication of WHOQOL-BREF in the context of Primary Health Care]. Cien Saúde Colet. 2017;22(5):1705-16. English, Portuguese.

12. Freitas EV. Tratado de geriatria e gerontologia. $3^{\mathrm{a}} \mathrm{ed}$. Rio de Janeiro: Guanabara Koogan; 2011. 1750p.

13. Pedroso B, Pilatti LA, Gutierrez GL, Picinin CT. Cálculo dos escores e estatística descritiva do WHOQOL-bref através do Microsoft Excel. Rev Bras Qual Vida. Ponta Grossa. 2010;2(1):31-6.

14. Castro, DFA. A. Qualidade de Vida de Gestantes assistidas pela Estratégia Saúde da Família [dissertação]. USP - Área de concentração: saúde coletiva. 2010. 196p.

15. Azevedo AL, Silva RA, Tomasi E, Quevedo LA. Doenças crônicas e qualidade de vida na atenção primária à saúde. Cad. Saúde Pública, 2010;29(9):1774-82.

16. Buss PM. Promoção da saúde e qualidade de vida. Ciênc Saúde Coletiva 2000;5:163-77.

17. Rabelo L, Garcia VL. Role-Play para o desenvolvimento de habilidades de comunicação e relacionais. Rev Bras Educ Med. 2015;39(4):586-96.

18. Wijma AJ, van Wilgen CP, Meeus M, Nijs J. Clinical biopsychosocial physiotherapy assessment of patients with chronic pain: the first step in pain neuroscience education. Physiother Theory Pract. 2016;32(5):368-84.

19. Conselho nacional de educação câmara de educaçáo superior resoluçáo CNE/CES 4, de 19 de fevereiro de 2002. Institui Diretrizes Curriculares Nacionais do Curso de Graduação em Fisioterapia. Diário Oficial da União, Brasília, 4 de março de 2002. Seção 1, 11p. 